\title{
FASTING BLOOD GLUCOSE LEVEL AND ALCOHOL CONSUMPTION AMONG MEN IN MENDAWAI PALANGKA RAYA
}

\author{
Glukosa Darah Puasa dan Konsumsi Alkohol pada Laki-Laki di Mendawai Kota Palangka Raya
}

\author{
${ }^{1 * S u r a t n o,}{ }^{2}$ Novidha Muji Rahayuningrum, $\mathbf{\&}^{3}$ Helmus \\ ${ }^{1,2,3}$ Medical Laboratory Technology, Faculty of Health Sciences, Universitas Muhammadiyah Palangkaraya, \\ Jl. RTA Milono Km 1,5, Palangka Raya, Indonesia \\ *e-mail: nono.suratno89@yahoo.com
}

\begin{abstract}
ABSTRAK
Konsumsi alkohol sering dikaitkan dengan kejadian diabetes mellitus. Penelitian ini bertujuan untuk mengetahui gambaran kadar glukosa darah puasadan konsumsi alkohol pada laki-laki di Mendawai, Palangka Raya, Kalimantan Tengah. Penelitian ini menggunakan desain cross-sectional studypada 20 laki-laki peminum alkohol yang diperoleh berdasarkan teknik purposive sampling. Pemeriksaan glukosa darah puasa dilakukan dengan teknik kolorimetrik enzimatik otomatis menggunakan fotometer (5010 V5+ Robert Riele).Penentuan kadar glukosa darah puasa menggunakan prinsip glucose oxidasedanperoxidase (GOD-POD).Hasil penelitian menunjukkan bahwa $40 \%$ peminum alkohol mempunyai glukosa darah puasa dalam kriteri tinggi dengan rerata139,6 mg/dL. Sebanyak 25\% peminum alkohol mempunyai glukosa darah puasa dalam kriteri rendah dengan rerata68,8 mg/dL. Dan sebanyak 35\% peminum alkohol glukosa darah puasa dalam kriteri normal dengan rerata 97,4 $\mathrm{mg} / \mathrm{dL}$.
\end{abstract}

Kata kunci:glukosa darah puasa, peminum alkohol, diabetes mellitus

\begin{abstract}
Alcohol consumption is often associated with the incidence of diabetes mellitus. This study aimed to examine fasting blood glucose levels and alcohol consumption in men in Mendawai, Palangka Raya, Central Kalimantan.Thecross-sectional studydesign was carried out to asses fasting blood glucose levels on 20 male alcohol drinkers. Blood glucose assay was determined by automated enzymatic colorimetric technique using Photometers (5010 V5+ Robert Riele). Determination of fasting blood glucose level using glucose oxidase and peroxidase (GOD-POD) method. This study found that 40\% alcohol drinker considered high fasting blood glucose level with average level $139.6 \mathrm{mg} / \mathrm{dL}$. Twenty five percent of alcohol drinkers considered low fasting blood glucose level with average $68.8 \mathrm{mg} / \mathrm{dL}$. And $35 \%$ of drinkers have normal level of fasting blood glucose with average $97.4 \mathrm{mg} / \mathrm{dL}$
\end{abstract}

Keyword: fasting blood glucose level, alcohol drinkers, diabetes mellitus,

\section{INTRODUCTION}

Alcohol consumption is often associated with the incidence of diabetes mellitus. A heavy alcohol consumption is considered to be a potential risk factor for the incidence of type 2 diabetes mellitus, which causes insulin resistance and pancreatic $\beta$-cell dysfunction that is a prerequisite for the development of diabetes (Wan et al., 2005; McKinlay\& Marceau, 2000).

Average daily alcohol consumption was associated with reduced risk of developing type 2 diabetes. Compared with zero alcohol consumption, consumption of 15-29 g/day of alcohol was associated with a $36 \%$ lower risk of diabetes.(Conigrave et al., 2001).However, this beneficial effects of alcohol intake remains controversial due to inconsistent results across studies.

Lee et al. (2017) reported that heavy drinking with $\geq 30 \mathrm{~g} /$ day alcohol consumption increased the risk of incident diabetes, but $\geq 5$ and $<30$ g/day alcohol consumption had no efectson the incident diabetes.This study aimed to examine fasting blood 
glucose levels and alcohol consumption in men in Mendawai, Palangka Raya, Central Kalimantan.

\section{METHODS}

A cross-sectional study design was conducted this study to examine fasting blood glucose level in male alcohol drinker. This study was carried out in Jalan Mendawai, Palangka Raya, Central Kalimantan inApril to May, 2018. The fasting glucose levels determination was conducted in Clinical Laboratory, Faculty of Health Science, Universitas Muhammadiyah Palangkaraya.

Purposive sampling was used as the sampling technique in this study. All samples were collected based on some certain purposes and considerations. The inclusion criteria of the sample must be: (a) male who had beendrinkingalcohollonger than one year, (b) in good health, and (c) voluntarily agree to be involved in this research proven by signed informed consent form. Twenty sample who met those criteria could complete the questionnaire. All samples were asked to fasting (no eat and drink 8-10 hours) andexamined the fasting blood glucose test.

\section{Tools and Materials}

The tools were used in this study consist of syringe 3 cc, micropipette $(1000 \mu \mathrm{L} \& 10 \mu \mathrm{L})$, blue and yellow micropipette tips, test tube, plain vacutainer blood tube, vortex mixer and centrifuge. The fasting blood glucose test was carried out using Photometers (5010 V5+ Robert Riele).The materials were used in this study consist of serum sample, Glucose Blood Test kit: Reagent 1 as an enzyme reagent (Phosphate buffer $\mathrm{pH}$ 7,5, 4-aminophenazone, phenol, glucose oxidase, peroxidase, mutarostase, and stabilizers) andReagent 2 as a standard (glucose), and alcohol swab $70 \%$.

\section{Data and Sample Collection}

All data obtained during the questionnaire and the fasting blood glucose assay of the alcohol drinkers' blood. The questionnaire items included general information, duration of alcohol consumption, the amount of alcohol consumedand tipe of alcohol.

The blood sample collection involved venipuncture procedure based on Department of Health of Republic of Indonesia 2008. The blood collected by venipuncture was collected in dry vacutainer tubes for fasting blood glucosedetermination.

Serum processing referred to Good Laboratory Practice Guidelines Department of Health of
Republic of Indonesia (2008). Blood sample was prior allowed

at room temperature for 1-2hours, tranferred into plain vacutainer blood tube, and centrifuged at 3000 rpm for15 min. The determination of fasting blood glucose level in serum was performed within $2 \mathrm{~h}$ after sample collection.

The fasting blood glucose level was obtained using an automated enzymatic colorimetric technique. Determination of fasting blood glucose level using Glucose oxidase and peroxidase (GOD-POD) method. The glucose is determined after enzymatic oxidation in the presence of glucose oxidase. The formed hydrogen peoxidase reacts under catalysis of peroxidase eith phenol and 4-aminophenazone to ared-violet quinoneimine dye as indicator, measured at $500 \mathrm{~nm}$.

\section{RESULTS AND DISCUSSION}

The characteristics of the sample

The sample of this study consisted of 20 alcohol drinkers. All alchohol drinkers were men. E-cig users were mostlyadults as $45 \%$ of were aged 36 to 40 years, and $30 \%$ were aged 41 to 45 years. Duration of drinking indicates period of drinking alcohol from the first-time usage until this study conducted. As $70 \%$ of alcohol drinkers had been drinking alcohol for 5-10 years(Table 1).

Table 1. Characteristics of the samples

Table 1. Characteristics of the samples
\begin{tabular}{|l|c|c|c|}
\hline Characteristics & Variables & Number & $\begin{array}{c}\text { Percentage } \\
(\mathbf{\%})\end{array}$ \\
\hline Age category, $\mathbf{y}$ & $25-30$ & 2 & 10 \\
\cline { 2 - 4 } & $31-35$ & 3 & 15 \\
\cline { 2 - 4 } & $36-40$ & 9 & 45 \\
\cline { 2 - 4 } & $41-45$ & 6 & 30 \\
\hline $\begin{array}{l}\text { Duration of } \\
\text { alcohol } \\
\text { consumption, } \mathbf{y}\end{array}$ & $5-10$ & 14 & 70 \\
\cline { 2 - 4 } & $11-15$ & 6 & 30 \\
\hline
\end{tabular}

\section{The Fasting Blood Glucose Level on Alcohol Drinker}

The normal range for serum fasting blood glucose levels were 75 to $115 \mathrm{mg} / \mathrm{dL}$. The fasting blood 
Table2.Fasting blood glucose levels on alcohol drinkers

\begin{tabular}{|c|c|c|c|}
\hline $\begin{array}{c}\text { Fasting blood glucose levels } \\
\text { classifications }\end{array}$ & Number & $\begin{array}{c}\text { Percentage } \\
(\boldsymbol{\%})\end{array}$ & $\begin{array}{c}\text { Average fasting blood } \\
\text { glucose level (mg/dL) }\end{array}$ \\
\hline Low $(\leq 75 \mathrm{mg} / \mathrm{dL})$ & 5 & 25 & 68.8 \\
\hline Normal $(75-115 \mathrm{mg} / \mathrm{dL})$ & 7 & 35 & 97.4 \\
\hline High $(115 \mathrm{mg} / \mathrm{dL})$ & 8 & 40 & 139.6 \\
\hline
\end{tabular}

glucose levels was considered high when higher than the normal range. This study found that mostly alcohol drinker considered high blood glucose level as $40 \%$ with average level $139.6 \mathrm{mg} / \mathrm{dL}$. As $25 \%$ of alcohol drinkers considered low level of blood glucose with average $68.8 \mathrm{mg} / \mathrm{dL}$. As35\% of drinkershave normal level of fasting blood glucose with average $97.4 \mathrm{mg} / \mathrm{dL}$ (Table 2).

A study about glycaemic effects of regular moderate alcohol in patients with type 2 diabetes who had previouslyabstained.They drank $150 \mathrm{~mL}$ of wine or non-alcoholic diet beerdaily for three months. Among participants who drankalcohol fasting plasma glucose decreased from $139.6 \pm 41$ to $118.0 \pm 32.5 \mathrm{mg} / \mathrm{dL}$ after three months compared with136.7 \pm 15.4 to $138.6 \pm 27.8 \mathrm{mg} / \mathrm{dl}$ in the control subjects (Shai et al., 2007).

However, this study also found that $40 \%$ alcohol drinker considered high blood glucose level with average level $139.6 \mathrm{mg} / \mathrm{dL}$. Baliunas et al. (2009) reported that compared with lifetime abstainers of drinkring alcohol, the risk of type 2 diabetes among men with prolonged heavy alcohol intake (over 60 $\mathrm{g}$ /day alcohol) was became deleterious effect.

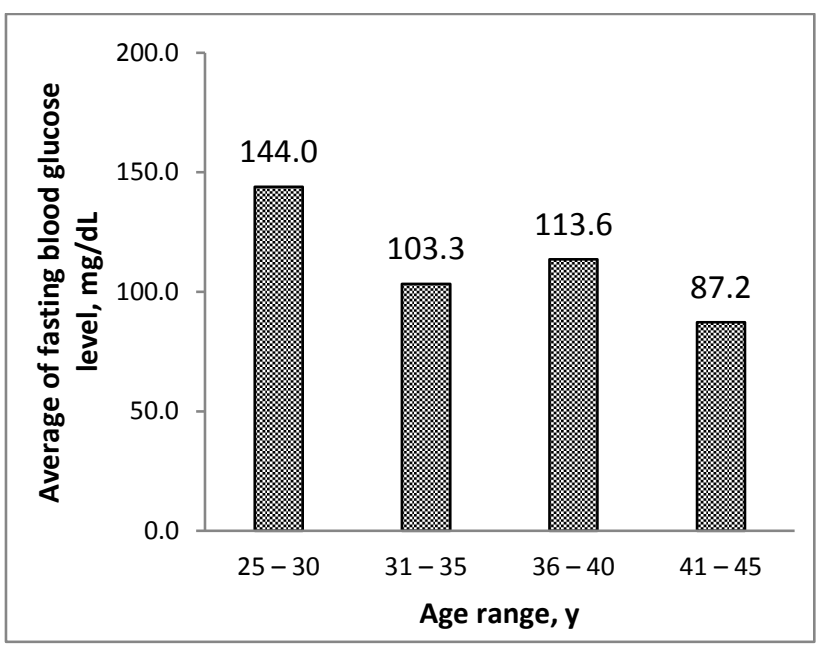

Figure 1.The average of fasting blood glucose levels based on age
Figure 1 shows the average of fasting blood glucose levels based on age range of alcohol drinkers. The average fasting blood glucoselevels of 25-30 year-old men drinker was highest among ather age group.

A significant difference in fasting blood glucose level and alcohol consumption among young adults. Young adults consuming alcohol between 3-5 days within the past month had significantly lower fasting glucose level in blood compared to students who did not report alcohol consumption within the last month and those who reported drinking more. It shows that moderate alcohol consumption is associated with lower fasting blood glucose concentrations and may reduce the risk for developing type II diabetes (Lucca, 2013).

Compared with non-high-risk alcohol drinking, highrisk drinking for men( $\geq 7$ glasses at a sitting) was associated with higher odds ratios of impaired fasting glucose(IFG)and diabetes mellitus (Lim et al., 2018).

Alcoholic beverage consumption lowers postprandial glycemia by $16-37 \%$, which represents an unrecognized mechanism by which alcohol may reduce the risk ofchronic disease (Brand-Miller et al., 2007).

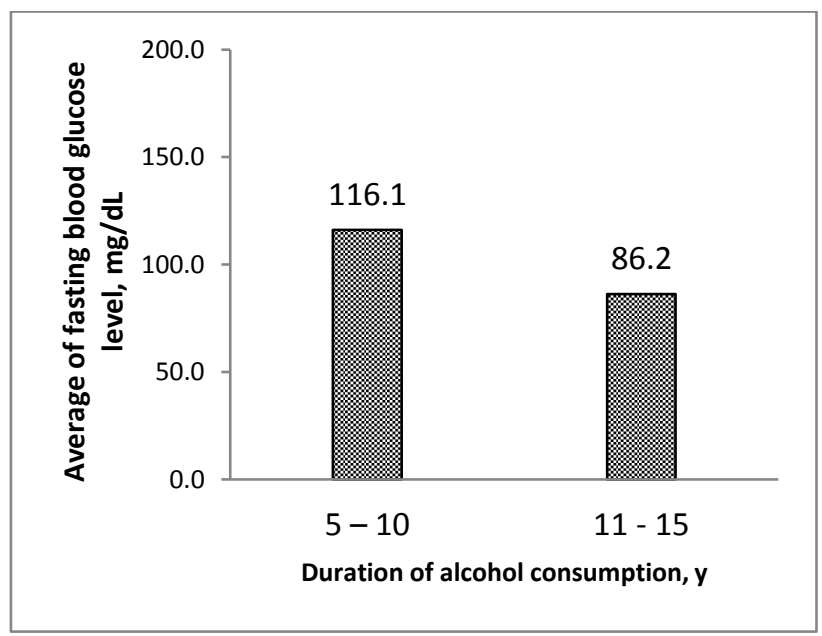

Figure2. The average of fasting blood glucose levels based on duration of alcohol consumption 
Figure 2 shows the average fasting blood glucose levels based on duration of alcohol consumption. Alcohol consumption 5 to 10 years lead to higher the average fasting blood glucose levels than 11-15 years consumption. Drinking alcohol increases the risk of hypoglycaemia in people on insulin (Hillson, 2015).

Funayama et al. (2017) reported that one week alcohol abstinence improved hepatic insulin sensitivity and fasting plasma glucose (FPG) in nonobese Japanese men with mildly elevated FPG and drinking habits alcohol.

Leggio et al. (2010) evaluated the relationship between baseline (pre-treatment) glucose levels and percentage of heavy drinking day (PHDD) duringtreatment. Higher glucose levels at baselinewere associated with a higher percentage of PHDD at pretreatment.

\section{CONCLUSION}

This study found that $40 \%$ alcohol drinker considered high fasting blood glucose level with average level $139.6 \mathrm{mg} / \mathrm{dL}$. Twenty five percent of alcohol drinkers considered lowfasting blood glucose level with average $68.8 \mathrm{mg} / \mathrm{dL}$. And35\% of drinkershave normal level of fasting blood glucose with average $97.4 \mathrm{mg} / \mathrm{dL}$.

\section{BIBLIOGRAPHY}

Baliunas, D.O., B.J. Taylor,H. Irving,M. Roerecke,J. Patra,S. Mohapatra,J. Rehm. 2009. Alcohol as a Risk Factor for Type 2 Diabetes: A systematic review and meta-analysis. Diabetes Care. 32(11): 2123-32.

Brand-Miller, J.C., K. Fatima, C. Middlemiss, M. Bare, V. Liu, F. Atkinson, \&P. Petocz. 2007. Effect of alcoholic beverages on postprandial glycemia and insulinemia in lean, young, healthy adults. Am J Clin Nutr. 85:1545-51.

Conigrave, K.M., B.F. Hu,C.A. Camargo, Jr.,M.J. Stampfer,W.C. Willett,\& E.B. Rimm. 2001. A prospective study of drinking patterns in relation to risk of type 2 diabetes among men. Diabetes. 50:2390 -2395.

Department of Health of Republic of Indonesia. 2008. Good laboratory practice. Jakarta,
Department of Health of Republic of Indonesia.

Funayama, T., Y. Tamura, K. Takeno, M. Kawaguchi, S. Kakehi, T. Watanabe, Y. Furukawa, H. Kaga, R. Yamamoto, A. Kanazawa, Y. Fujitani, R. Kawamori, \&H. Watada. 2017. Effects of alcohol abstinence on glucose metabolism in Japanese men with elevated fasting glucose: A pilot study. Scientific Reports. 7:40277.

Hillson, R. 2015. Diabetes and alcohol. Practical Diabetes. 32(6): 195-196.

McKinlay, J, L. Marceau. 2000. US public health and the 21 st century: diabetes mellitus. Lancet. 356:757-61.

Lee, D.Y., M.G. Yoo, H.J. Kim, H.B. Jang, J.H. Kim, H.J. Lee, \& S.I. Park. 2017. Association between alcohol consumption pattern and theincidence risk of type 2 diabetes in Korean men: A 12-years follow-up study. Scientific Reports. 7:7322.

Leggio, L., L.A. Ray, G.A. Kenna, \&R.M. Swift. 2009. Blood Glucose Level, Alcohol Heavy Drinking and AlcoholCraving during Treatment for Alcohol Dependence: Results from the Combined Pharmacotherapies and Behavioral Interventions for Alcohol Dependence (COMBINE) Study. Alcohol Clin Exp Res. 33(9): 1539-1544.

Lim, J., J.A. Lee, \& H.J. Cho. 2018. Association of alcohol drinking patterns with presenceof impaired fasting glucose and diabetes mellitusamong south korean adults. $J$ Epidemiol. 28(3):117-124.

Lucca, J. 2013. Associations between alcohol consumption and fasting blood glucose in young adults. Thesis. the Faculty of California Polytechnic State University,San Luis Obispo.

Shai, I., J. Wainstein, I. Harman-Boehm, I. Raz, D. Fraser, A. Rudich, \& M.J. Stampfer. 2007. Glycemic effects of moderate alcohol intake among patients with type 2 diabetes. A multicenter, randomized, clinical intervention trial. Diabetes Care. 30:3011-6.

Wan, Q, Y. Liu, Q. Guan, L. Gao, K.O. Lee, J. Zhao. 2005. Ethanol feeding impairs insulinstimulated glucose uptake in isolated rat 
Alcohol Clin Exp Res. 29:1450-6. 